\title{
Caries prevalence among 18 years old, an epidemiological survey in Israel
}

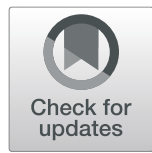

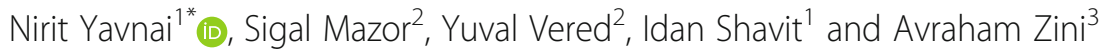

\begin{abstract}
Background: There is a lack of evidence on caries prevalence among 18 years old Israeli young adults with only a scarce evidence regarding this index age group. In the last few years dental care policy in Israel underwent substantial changes and a major reform in dental services was led by the Israeli Ministry of Health, including coverage of dental care for children by the state. In addition, a cessation of community water fluoridation was in a debate.

The objective of the current study was to describe prevalence of caries among 18 years old Israeli young adults and to evaluate possible associations with personal and demographic variables.

Methods: The study was a cross sectional clustered survey. Participants were recruited to the study at their first day of military service. Participants completed a questionnaire for personal and demographic data, including: age, country of birth, education, and current smoking status. Then participants underwent clinical evaluation included DMFT and caries free rates. No radiographic evaluation was included in the current study. Univariate and multivariate statistical analysis were performed.

Results: A total of 702 participants were included in the study, 58.4\% were males. Their mean age was $19.03 \pm 0.65$ years, $91.3 \%$ of the participants were born in Israel. Mean DMFT was $1.95 \pm 2.67$, and $46.7 \%(n=328)$ were caries free. Higher DMFT score was significantly associated with participant's parents' education, country of birth, and smoking status. Lower caries free rates were significantly associated with participant's parents' education, and smoking status. After linear regression for total DMFT, all variables were significant predictors to higher DMFT, except father's education, while logistic regression for caries free, only mother's education was found to be a significant predictor.
\end{abstract}

Conclusions: The current study presents encouraging low DMFT levels. Participants in this study were not included in the dental care services reform, and did enjoy the benefits of water fluoridation, enabling the results to play an important baseline data for future reference. Additionally, results should be considered when planning intervention programs for at risk groups.

Trial registration: This study was registered in ClinicalTrials.gov (Identifier No. NCT02958891, November 8th, 2016) and was approved by the IDF Institutional Review Board (\#1524-2015).

Keywords: Caries, Prevalence, 18 years old

\footnotetext{
* Correspondence: nirityavnai@gmail.com

'IDF Medical Corps Headquarters, Military Post \#02149, IDF, Tel Hashomer, Ramat Gan, Israel

Full list of author information is available at the end of the article
}

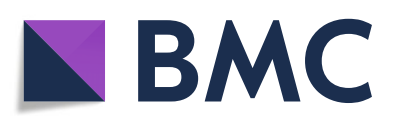

(- The Author(s). 2020 Open Access This article is licensed under a Creative Commons Attribution 4.0 International License, which permits use, sharing, adaptation, distribution and reproduction in any medium or format, as long as you give appropriate credit to the original author(s) and the source, provide a link to the Creative Commons licence, and indicate if changes were made. The images or other third party material in this article are included in the article's Creative Commons licence, unless indicated otherwise in a credit line to the material. If material is not included in the article's Creative Commons licence and your intended use is not permitted by statutory regulation or exceeds the permitted use, you will need to obtain permission directly from the copyright holder. To view a copy of this licence, visit http://creativecommons.org/licenses/by/4.0/. The Creative Commons Public Domain Dedication waiver (http://creativecommons.org/publicdomain/zero/1.0/) applies to the data made available in this article, unless otherwise stated in a credit line to the data. 


\section{Background}

The last nation-wide significant-extent dental epidemiological survey was published almost two decades ago, describing caries prevalence in Israel among 21 years old military personnel at their day of discharge from the mandatory military service [1]. Some additional scarce evidence regarding caries prevalence among 18 years old in Israel were found in a research aimed to evaluate association between caries prevalence and black extrinsic discoloration [2]. Mean DMFT was 4.2-5.98 (with standard deviation of 3.9-4.8) for a wide range inhomogeneous age group of 18-29-year-old participants. In a very local survey, mean DMFT among 18-19 Israeli military recruits was $6.09 \pm 5.29$ with $17.2 \%$ caries free rate [3]. Since these publications, no representative national epidemiological survey regarding caries prevalence in Israel among 18 years old has been published yet, nor did any additional study of caries prevalence among this age group, although this age group is defined by the World Health Organization (WHO) as an index group.

Prior to 2010, besides specific primary prevention program given at primary schools, dental treatment for children and adolescents in Israel was the sole responsibility of their parents and was paid in a largely privately funded delivery system [4]. In the last few years dental care policy in Israel underwent substantial changes [5]. The major and significant reform occurred in 2010 with the inclusion of dental care in the National Health Insurance Law services' basket, by covering dental care to children by the state [4-6]. This reform was performed gradually, starting by including dental treatment to children from birth to 8 years old, and was eventually broadened to the age 18 nowadays.

The rationale behind this reform was to cover all basic dental treatment needs for children until one enters the mandatory military service at the age of 18 , where he is eligible to receive most of his dental treatment needs in the military setting.

In addition, Community water fluoridation was the main prevention policy of the Israeli Ministry of Health for many years. In recent years, there have been some changes in this policy in Israel [7], and in 2014 the policy was changed, and community water fluoridation was stopped [4]. In 2016 the Ministry of Health had reapproved regulations and renewal of water fluoridation policy, but, due to procedural and technical issues, water fluoridation is still not renewed.

The purpose of this study was to describe prevalence of caries among 18 years old military recruits and to evaluate possible associations with personal and demographic variables. The results of this survey would be helpful for service planning and for future reference, in order to evaluate the effect of the reform in dental services and the cessation of water fluoridation on dental health in Israel.

\section{Methods}

The study was a cross sectional clustered survey. The sampling frame was all military recruits in 2016. Specific recruitment days were chosen for data collection as clusters, to enable representation to all military professions for both genders along 2016 at the solely unique recruitment base of the Israel Defense Forces (IDF) in the center of Israel. Participants were recruited to the study at their first day of military service. The data was collected at the military recruitment process that every military recruit must undergo, between March and August 2016. Inclusion criteria were military recruits, at their first day of military service, from both genders, 18 or more years old. Exclusion criteria were having chronic bone diseases, any skeleton development defects or calcification impairments in calcified tissues.

Sample size was calculated using Raosoft website [8] with the following assumptions: confidence level of $99 \%$ $(\alpha=1 \%)$, response rate of $50 \%$, assumed population size of 100,000 (based on the Israeli Bureau of Statistics data) and an in-study attrition rate of $5 \%$. The total sample size was 700 participants.

After signing an informed consent form, participants completed a self reporting questionnaire collecting data regarding demographic and personal data including age, country of birth, participant and parents' education (elementary/high school/has a matriculation diploma/ academic) and current smoking status (yes/no). Then participants had a clinical examination by one of the five study dentists (N.Y., S.M., Y.V., I.S. and A.Z.). Calibration between the study dentists was performed prior to data collection days. Twenty different cases were evaluated and discussed by all five certified dentists who were the researchers in this study (Kappa $=0.7-0.8$ ).

Caries history was evaluated by Decayed, Missing, Filled Tooth index (DMFT) for all available permanent teeth. Wisdom teeth were excluded. The evaluation was performed according to the WHO instructions for caries diagnosis for epidemiological surveys, using a dental mirror and a WHO dental probe for caries detection [9].

Mean DMFT score was calculated for each participant. All dental measurements were performed using standard office chair with office mixed with natural window illumination. No dental unit was involved, neither dental light nor triple syringe. No radiographic evaluation was included in the current study.

Statistical analysis included Chi square and $t$ tests for univariate analyses. A linear regression and logistic regression models were built for multivariate analyses. Multivariate models included significant variables from the univariate analyses, additionally to age and gender adjustment. Level of significance was set to $P<0.05$.

The study was approved by the IDF Institutional Review Board (IRB) (\#1524-2015) and was conducted in full accordance with all ethical principles. 


\section{Results}

A total of 702 participants were included in the study. Of them, $58.4 \%$ were males, mean age was $19.03 \pm 0.65$ years. Almost all of the participants (91.3\%) were born in Israel. Most of the participants (80.1\%) had finished high school and were eligible for a matriculation diploma. Parents' educational status showed that most of participants' parents did not have an academic degree. A fifth (19.9\%) reported current smoking. Additional personal data is presented in Table 1.

Mean DMFT was $1.95 \pm 2.67(\mathrm{D}=0.52 \pm 1.19 ; \mathrm{M}=$ $0.03 \pm 0.17 ; F=1.40 \pm 2.32$ ). Higher DMFT score was significantly associated with poor education of participants' parents $(P<0.001$ for mother's education; $P=0.002$ for father's education), born outside of Israel $(P=0.013)$ and a current smoker $(P=0.003)$ (Total DMFT results are presented in Table 1). Age was significantly correlated with DMFT (Pearson coefficient $=0.087 ; P=0.021$ ).

Caries free rate was $46.7 \%(n=328)$ among the participants. Lower caries free rates were significantly associated with poor education of participants' parents $(P=$ 0.002 for mother's education; $P=0.010$ for father's education), and being a current smoker $(P=0.013)$. Caries free rates were not significantly associated with age $(P=$ 0.106) (Table 1).
After linear regression for total DMFT $\left(\mathrm{R}^{2}=0.056\right.$; $P<$ $0.001)$, country of birth, age, mother's education, and smoking status were significant predictors to higher DMFT (Table 2). After multivariate logistic regression (Table 3) only mother's education was a significant predictor to caries free (Nagelkerke $\mathrm{R}^{2}=0.045 ; P=0.002$ ).

\section{Discussion}

This study analyzed data regarding caries experience and demographic variables of seven hundred and two 18 years old Israeli military recruits on their first day of military service. Its predominant advantage is the representativeness of the sample which is optimally representative of Israeli young healthy adults. The distribution of genders is similar and representative of the recruitment gender rate among Israeli youth.

This study presents some unexpected and encouraging findings of low DMFT scores and high caries free rates comparing to previous published data [1-3]. Data among this age group from the world presented higher DMFT scores, though the trend of decrease was similar [10-12].

The epidemiology of dental diseases has clearly been described as a web of connecting factors, including biological, social, psychological, economic, environmental and other variables [13] and many socio-demographic

Table 1 Distribution of personal and demographic data with participants' DMFT ${ }^{\mathrm{a}}$ levels and caries free prevalence

\begin{tabular}{|c|c|c|c|c|c|c|}
\hline & \multirow[t]{2}{*}{ N (\%) } & \multirow[t]{2}{*}{$\operatorname{DMFT}\left(\mathrm{SD}^{\mathrm{b}}\right)$} & \multirow[t]{2}{*}{$P$ value (t test) } & \multicolumn{2}{|c|}{ Caries Free N (\%) } & \multirow[t]{2}{*}{$P$ value ( $X^{2}$ test) } \\
\hline & & & & No & Yes & \\
\hline Gender & & & 0.879 & & & 0.889 \\
\hline Male & $395(58.4)$ & $1.95(2.75)$ & & $213(53.9)$ & $182(46.1)$ & \\
\hline Female & $281(41.6)$ & $1.97(2.55)$ & & $150(53.4)$ & $131(46.6)$ & \\
\hline Participant's Education (has matriculation diploma) & & & 0.090 & & & 0.132 \\
\hline Yes & $559(80.1)$ & $1.86(2.63)$ & & $290(51.9)$ & $269(48.1)$ & \\
\hline No & $139(19.9)$ & $2.29(2.82)$ & & $82(59.0)$ & $57(41.0)$ & \\
\hline Mother's Education & & & $<0.001$ & & & 0.002 \\
\hline Academic & $322(47.7)$ & $1.49(2.23)$ & & $213(53.9)$ & $182(46.1)$ & \\
\hline Else & $353(52.3)$ & $2.30(2.86)$ & & $150(53.4)$ & $131(46.6)$ & \\
\hline Father's Education & & & 0.002 & & & 0.010 \\
\hline Academic & $297(45.2)$ & $1.55(2.38)$ & & $207(57.5)$ & $153(42.5)$ & \\
\hline Else & $360(54.8)$ & $2.18(2.72)$ & & $141(47.5)$ & $156(52.5)$ & \\
\hline Country of Birth & & & 0.013 & & & 0.679 \\
\hline Israel & $640(91.3)$ & $1.87(2.61)$ & & $339(53.0)$ & $301(47.0)$ & \\
\hline Other & $61(8.7)$ & $2.75(3.16)$ & & $34(55.7)$ & $27(44.3)$ & \\
\hline Current Smoker & & & 0.003 & & & 0.013 \\
\hline Yes & 139 (19.9) & $2.55(3.11)$ & & $87(62.6)$ & $52(37.4)$ & \\
\hline No & $560(80.1)$ & $1.80(2.54)$ & & $285(50.9)$ & $275(49.1)$ & \\
\hline Total & & $1.95(2.67)$ & & $374(53.3)$ & $328(46.7)$ & \\
\hline
\end{tabular}

${ }^{\mathrm{a} D e c a y e d, ~ M i s s i n g ~ o r ~ F i l l e d ~ T e e t h ~}$

${ }^{\mathrm{b}}$ Standard Deviation 
Table 2 Multiple Linear Regression Model for significant independent variables effect on total DMFT $\left(P<0.001, R^{2}=0.065\right)$ (adjusted for gender and age)

\begin{tabular}{lllll}
\hline & B & Beta & $P$ value & Confidence Interval \\
\hline Constant & -5.532 & - & 0.066 & $-11.438-0.373$ \\
Country of Birth (Israel vs. ${ }^{\text {b Other) }}$ & -1.323 & -0.137 & $<0.001$ & $-2.065--0.581$ \\
Gender (Male vs. Female) & 0.199 & 0.038 & 0.352 & $-0.220-0.618$ \\
Age (Continuous variable) & 0.468 & 0.120 & 0.003 & $0.162-0.774$ \\
Mother's Education (Academic vs. Else) & -0.735 & -0.142 & 0.005 & $-1.250--0.220$ \\
Father's Education (Academic vs. Else) & -0.179 & -0.034 & 0.503 & $-0.702-0.345$ \\
Current Smoker (Yes vs. No) & 0.563 & 0.084 & 0.040 & $0.026-1.101$ \\
\hline
\end{tabular}

${ }^{a}$ Decayed, Missing or Filled Teeth

bersus

markers were already been shown to be associated with caries prevalence [14]. Previous studies conducted in Israel showed significant associations between education, country of birth, smoking and caries experience [1, 14, 15]. Additionally, Levy et al. had showed a statistically significant association between low intellectual capabilities and higher dental treatment needs among IDF soldiers, and implied for an association with parental education, similarly to other published studies and to the current study results $[14,16,17]$. Parental education level had been previously found to be associated with oral health outcomes, and specifically, with caries prevalence in many studies [18-20]. The odds of having any caries experience (DMFT $>0$ ) were found to be significantly greater in those with low parental educational or occupational background [21], thus, the results of the current study support former evidence.

Table 3 Multivariate Logistic Regression Model for significant independent variables effect on caries free among 18 years old Israeli recruits $\left(P=0.027\right.$, Nagelkerke $\left.R^{2}=0.045\right)$ (adjusted for gender and age)

\begin{tabular}{|c|c|c|c|c|}
\hline & $B$ & $P$ value & $\mathrm{OR}^{a}$ & Confidence Interval \\
\hline Constant & 4.962 & 0.050 & 142.879 & - \\
\hline \multicolumn{5}{|c|}{ Country of Birth } \\
\hline Other & - & - & 1.000 & - \\
\hline Israel & 0.377 & 0.228 & 1.458 & $0.790-2.692$ \\
\hline \multicolumn{5}{|c|}{ Mother's Education } \\
\hline Else & - & - & 1.000 & - \\
\hline Academic & 0.425 & 0.045 & 1.529 & $1.010-2.315$ \\
\hline \multicolumn{5}{|c|}{ Father's Education } \\
\hline Else & - & - & 1.000 & - \\
\hline Academic & 0.174 & 0.417 & 1.190 & $0.782-1.813$ \\
\hline \multicolumn{5}{|c|}{ Current Smoker } \\
\hline No & - & - & 1.000 & - \\
\hline Yes & -0.378 & 0.093 & 0.685 & $0.440-1.066$ \\
\hline
\end{tabular}

${ }^{\text {aOdds Ratio }}$
Additionally, current smoking was found as a significant predictor to higher DMFT. These results are similar to the scientific literature and the association between smoking and caries prevalence is well established in the literature $[22,23]$.

Caution should be taken with these findings since although military service is mandatory in Israel, there are two communities (Jewish Orthodox and Arabs) that are partially exempt from military service. However, these communities were not represented in former surveys, allowing comparability with previous studies conducted in the Israeli military setting.

It is important to mention that using the DMFT index for evaluation of caries prevalence has some well-known limitations: it is based on clinical evaluation without X-ray imaging, thus might underestimates caries prevalence [24]; has some potential inter-observer bias and variability [25]; gives equal weight to untreated decay, missing and filled teeth; does not refer to reasons for tooth loss [26]; and does not provide useful treatment needs estimation [27].In the last decade, the Israeli Ministry of Health has led and implemented a major reform and expanded the prevention and treatment programs in the dental health services, mainly for children and adolescents $[4,5]$. In the near future, with these programs implemented, soldiers should need less dental treatment [4]. The current study was performed among 18 years old youngsters who were not included in the dental care services reform, and did enjoy the benefits of water fluoridation during their adolescence years, enabling the results to play an important baseline data for future reference to assess the effect of these significant changes. We suggest that future evaluation studies for the efficacy of the Israeli dental services reform might possibly find different $\mathrm{F}$ to $\mathrm{D}$ components ratio within the DMFT scores.

The current study with the presented low DMFT levels should help monitoring dental health among this age group while the Israeli dental care services reform is proceeding. According to our results, some suggested risk factors including, being a current smoker, not being 
born in Israel and with low parental education may be associated with higher DMFT levels. Nevertheless, the encouraging results of caries prevalence may suggest to the Ministry of Health dental services, and specifically to the IDF dental department, to consider focused comprehensive preventive programs, while using these supporting scientific evidence to refine at risk populations (males, current smokers, from immigrant families with low parental education), while continue monitoring caries prevalence among all groups.

\section{Conclusions}

The results enabling national and international comparisons of caries prevalence within this important index group. In addition, the results can offer a unique opportunity to explore the Israeli dental health services reform and perform an evidence-based evaluations and substantial national follow up survey after the community water fluoridation cessation. In Addition, results should be considered when planning prevention intervention programs for designated at risk groups, such as current smokers or for those who were not born in Israel, since the IDF has some unique capabilities to outreach specific selected populations.

\section{Abbreviations}

IDF: Israel Defense Forces; WHO: World Health Organization; DMFT: Decayed, Missing, Filled Tooth; IRB: Institutional Review Board

\section{Acknowledgements}

Not applicable.

\section{Authors' contributions}

NY and AZ initiated the study concept and designed it. All authors participated in data collection. NY, AZ, YV and SM analyzed the data and had a significant contribution to data interpretation. All authors contributed to drafting the manuscript, revised the final version and approved the final version.

\section{Funding}

This study was supported by a research grant from the IDF Medical Corps and DDR\&D IMOD [20,000\$, grant \#4440708161].

\section{Availability of data and materials}

The datasets used and analyzed during the current study are available from the corresponding author on reasonable request.

\section{Ethics approval and consent to participate}

This study was registered in ClinicalTrials.gov (Identifier No. NCT02958891, November 8th, 2016) and was approved by the IDF Institutional Review Board (\#1524-2015). Each participant signed an informed consent.

\section{Consent for publication}

Not applicable.

\section{Competing interests}

All authors declare that they have no competing interests.

\section{Author details}

'IDF Medical Corps Headquarters, Military Post \#02149, IDF, Tel Hashomer, Ramat Gan, Israel. ${ }^{2}$ Department of Community Dentistry, Faculty of Dental Medicine, Hebrew University, Hadassah Ein Kerem Campus, Jerusalem, Israel. ${ }^{3}$ Vice Dean and the Department of Community Dentistry, Hebrew
University-Hadassah School of Dental Medicine, Hadassah Ein Kerem Campus, Jerusalem, Israel.

Received: 10 March 2020 Accepted: 21 August 2020

Published online: 31 August 2020

\section{References}

1. Sgan-Cohen HD, Katz J, Horev T, Dinte A, Eldad A. Trends in caries and associated variables among young Israeli adults over 5 decades. Community Dent Oral Epidemiol. 2000;28:234-40.

2. Shmuly T, Zini A, Yitschaky M, Yitschaky O. Can black extrinsic tooth discoloration predict a lower caries score rate in young adults? Quintessence Int. 2014;45:439-44.

3. Shenkman A, Levin L. Dental caries status and derived treatment needs among young Israeli adults - a clinical and radiographic study. Refuat Hapeh Vehashinayim (1993). 2007;24:53-4.

4. Zusman SP. Prevention, prevention and prevention. Isr J Health Policy Res. 2019;8(1):40

5. Natapov L, Sasson A, Zusman SP. Does dental heath of 6-year-olds reflect the reform of the Israeli dental care system? Isr J Health Policy Res. 2016;5: 26.

6. Quinonez C. Dental reform in Israel's National Health Insurance law has helped children and their families, but what's next? Isr J Health Policy Res. 2016:5:54.

7. Siegel-Itzkovich J. Israel's health minister stuns experts by ending mandatory fluoridation. BMJ. 2014;349:95240.

8. Sample size calculator by Raosoft. http://www.raosoft.com/samplesize.html. Accessed 10 Sept 2014.

9. Petersen PE, Baez RJ. World Health Organization, Oral health surveys: basic methods. 5th ed. France: WHO; 2013.

10. Hopcraft M, Morgan MV. Dental caries experience in a young adult military population. Aust Dent J. 2003:48:125-9.

11. Drachev SN, Brenn T, Trovik TA. Dental caries experience and determinants in young adults of the Northern State Medical University, Arkhangelsk, North-West Russia: a cross-sectional study. BMC Oral Health. 2017;17:136.

12. Žemaitienè M, Grigalauskienè R, Vasiliauskienè I, Saldūnaitè K, Razmienè J, Slabšinskienè E. Prevalence and severity of dental caries among 18-year-old Lithuanian adolescents. Medicina (Kaunas). 2016;52:54-60.

13. Marmot M, Bell R. Social determinants and dental health. Adv Dent Res. 2011;23(2):201-6.

14. Levy DH, Livny A, Sgan-Cohen H, Yavnai N. The association between caries related treatment needs and socio-demographic variables among young Israeli adults: a record based cross sectional study. Isr J Health Policy Res. 2018;7(1):24.

15. Birnboim-Blau G, Levin L, Sgan-Cohen HD. Dental status among native and immigrant young Israeli adults. Refuat Hapeh Vehashinayim (1993). 2006; 23(1):6-11.

16. Kato H, Tanaka K, Shimizu K, Nagata C, Furukawa S, Arakawa M, Miyake Y. Parental occupations, educational levels, and income and prevalence of dental caries in 3-year-old Japanese children. Environ Health Prev Med. 2017;22(1):80.

17. Crocombe LA, Allen P, Bettiol S, Babo Soares LF. Parental education level and dental caries in school children living in Dili, Timor-Leste. Asia Pac J Public Health. 2018;30(2):128-36.

18. Colak H, Dülgergil CT, Dalli M, Hamidi MM. Early childhood caries update: a review of causes, diagnoses, and treatments. J Nat Sci Biol Med. 2013;4(1): 29-38.

19. Pierce A, Singh S, Lee J, Grant C, Cruz de Jesus V, Schroth RJ. The burden of early childhood caries in Canadian children and associated risk factors. Front Public Health. 2019;7:328.

20. Anil S, Anand PS. Early childhood caries: prevalence, risk factors, and prevention. Front Pediatr. 2017:5:157.

21. Schwendicke F, Dörfer CE, Schlattmann P, Foster Page L, Thomson WM, Paris S. Socioeconomic inequality and caries: a systematic review and metaanalysis. J Dent Res. 2015;94(1):10-8.

22. Petersson GH, Twetman S. Tobacco use and caries increment in young adults: a prospective observational study. BMC Res Notes. 2019;12(1):218.

23. de Araújo NM, Maló P. Prevalence of periodontitis, dental caries, and periimplant pathology and their relation with systemic status and smoking habits: results of an open-cohort study with 22009 patients in a private rehabilitation center. J Dent. 2017:67:36-42. 
24. Zadik Y, Bechor R. Hidden occlusal caries: challenge for the dentist. N Y State Dent J. 2008;74(4):46-50.

25. Lesaffre $E$, Mwalili SM, Declerck D. Analysis of caries experience taking interobserver bias and variability into account. J Dent Res. 2004;83(12):951-5.

26. Broadbent JM, Thomson WM. For debate: problems with the DMF index pertinent to dental caries data analysis. Community Dent Oral Epidemiol. 2005;33(6):400-9.

27. Burt BA. How useful are cross-sectional data from surveys of dental caries? Community Dent Oral Epidemiol. 1997;25(1):36-41.

\section{Publisher's Note}

Springer Nature remains neutral with regard to jurisdictional claims in published maps and institutional affiliations.

Ready to submit your research? Choose BMC and benefit from:

- fast, convenient online submission

- thorough peer review by experienced researchers in your field

- rapid publication on acceptance

- support for research data, including large and complex data types

- gold Open Access which fosters wider collaboration and increased citations

- maximum visibility for your research: over $100 \mathrm{M}$ website views per year

At $\mathrm{BMC}$, research is always in progress.

Learn more biomedcentral.com/submissions 